\title{
PELUANG DAN TANTANGAN DALAM PENGELOLAAN SUMBERDAYA ALAM DALAM RANGKA OPTIMALISASI PENDAPATAN ASLI DAERAH STUDI DI SAMOTA (SATONDA MOYO DAN TAMBORA)
}

\author{
Kafrawi \\ Fakultas Hukum Universitas Mataram \\ Jl. Majapahit No.62 Mataram \\ Telp (0370) 633035, Fax 626954 \\ Email : -

\section{H. Abdul Khair} \\ Fakultas Hukum Universitas Mataram \\ Jl. Majapahit No.62 Mataram \\ Telp (0370) 633035, Fax 626954 \\ Email : - \\ M. Saleh \\ Fakultas Hukum Universitas Mataram \\ Jl. Majapahit No.62 Mataram \\ Telp (0370) 633035, Fax 626954 \\ Email : -

\section{Sarkawi} \\ Fakultas Hukum Universitas Mataram \\ Jl. Majapahit No.62 Mataram \\ Telp (0370) 633035, Fax 626954 \\ Email : -
}

\begin{abstract}
ABSTRAK
Penyelenggaraan pemerintahan daerah yang dilaksanakan berdasarkan asas otonomi dan tugas pembantuan sebagaimana telah diamanatkan dalam ketentuan Pasal 18 dalam UUD 1945 merupakan landasan konstitusional bagi daerah untuk membangun serta mengembangkan diri sesuai dengan prinsip otonomi daerah. Daerah diberikan keleluasaan dan kebebasan untuk mengatur dan mengurus segala urusan pemerintahan daerah menjadi urusan rumah tangga sendiri, sehingga dapat berinisiatif secara mandiri untuk merumuskan berbagai strategi kebijakan berdasarkan kebutuhan serta kepentingan yang dapat memberdayakan kehidupan masyarakat setempat. Pemerintahan daerah diberikan kemampuan (hak) untuk dapat berbuat serta tugas (kewajiban) yang harus dilakukan sesuai dengan ruang lingkup kewenangan sebagai daerah otonom. Bentuk tindakan nyata yang harus dimiliki oleh suatu daerah otonom adalah kemampuan untuk menggali serta mengembangkan potensi sumber daya alam menjadi Pendapatan Asli Daerah (PAD) sebagai sumber penerimaan utama. PAD salah satu tolok ukur dan/atau persyaratan untuk dapat dikategorikan sebagai daerah otonom dalam konsep otonomi daerah. Kewajiban bagi unsur penyelenggara pemerintahan daerah optimalisasi dalam upaya memperkuat/ memperbesar kemandirian daerah melalui PAD dengan intensifikasi maupun extensifikasi sumber penerimaan sebagai sendi utama dari esensi pelaksanaan otonomi daerah.
\end{abstract}




\section{A. PENDAHULUAN}

Penerapan otonomi daerah yang diikuti dengan desentralisasi kewenangan dalam penyelengaraan pemerintahan daerah di Indonesia, telah dirumuskan secara konstitusional bersamaan dengan lahirnya UUD 1945 sebagai hukum dasar tertulis dan tertinggi yang menganut prinsip negara hukum demokrasi. Prinsip negara hukum demokrasi menjadi landasan yuridis pengarah dan pengendali untuk menilai konstitusionalismenya pemerintahan, serta tidak membenarkan adanya sentralisasi kekuasaan yang bertentangan dengan makna demokrasi. Karena itu, Otonomi Daerah bukan merupakan suatu kebijakan yang baru dalam penyelenggaraan pemerintahan di Indonesia karena sejak berdirinya negara kesatuan Republik Indonesia sudah dikenal dan menganut prinsip otonomi daerah yang dipayungi oleh ketentuan Pasal 18 Undang-Undang Dasar 1945. ${ }^{1}$ Dan melalui otonomi daerah suatu bentuk pendistribusian kekuasaan negara kepada cabang kekuasaan di bawah sebagai penjabaran prinsip demokrasi sesuai dengan asas kedaulatan rakyat. Kedaulatan rakyat dalam penyelenggaraan pemerintahan daerah bertumpu pada prinsip pokok dari pelaksanaan otonomi daerah, yaitu terdapatnya keleluasaan/kebebasan pemerintahan daerah (dioscretionary power) untuk menyelenggarakan pemerintahan sendiri atas dasar prakarsa, kreatifitas, dan peran serta masyarakat dalam rangka mengembangkan dan memajukan daerahnya.

Perubahan pengaturan penyelenggaraan pemerintahan sebaimana yang dilakukan dengan Undang-undang Nomor 32 Tahun 2004 tentang Pemerintahan Daerah, telah membawa perubahan yang fundamental dalam sistem Pemerintahan Daerah, yaitu mengakui serta mengembalikan esensi kedaulatan rakyat bagi masyarakat di daerah yang selama ini terpasung dengan sistem pemerintahan yang sentralistik. Dengan

${ }^{1}$ Syamsudin Haris.(2005). Desentralisasi \& otonomi Daerah, Jakarta: LIPI Press, hlm. 101. demikian masyarakat di daerah telah dibuka haknya untuk ikut serta secara langsung dalam proses penyelenggaraan pemerintahan daerah sesuai dengan konsep penerapan prinsip otonomi daerah. Hal ini dapat dipahami dari makna yang terkandung dalam ketentuan Pasal 1 ayat (5) Undang-undang Nomor 32 Tahun 2004, Otonomi daerah adalah hak, wewenang dan kewajiban daerah otonom untuk mengatur dan mengurus sendiri urusan pemerintah dan kepentingan masyarakat setempat sesuai dengan peraturan perundangundangan. Secara normatif pemerintahan daerah diberikan kemampuan untuk bertindak/berbuat disertai bertanggung jawab atas kewajiban yang melekat atas kewenangan yang diserahkan sesuai dengan tujuan dari otonomi. Karena otonomi yang diterapkan adalah menganut prinsip otonomi nyata dan bertanggung jawab, sehingga kewenangan yang diserahkan sesuai dengan urusan yang harus dilaksanakan dapat direalisasikan secara kongkrit dan dapat dipertanggungjawabkan. Pemerintah memberikan kewenangan kepada pemerintahan daerah dengan otonomi luas untuk mengatur dan mengurus rumah tangganya berdasarkan inisiatif sendiri menurut kebutuhan serta kepentingan masyarakat yang dilaksanakan dengan produk hukum daerah.

Pelaksanaan Otonomi Daerah, dengan semangat membangun dari dan oleh kekuatan yang bermuara pada kemampuan PAD setempat dan harus ditopang dengan daya inovatif yang tinggi untuk melakukan pengembangan pengelolaan sumber-sumber penerimaan sebagai penguat PAD. Karena sesuai dengan sasaran dari penerapan otonomi daerah adalah untuk memberdayakan potensi sumber daya alam yang dimiliki oleh daerah setempat secara langsung guna mempercepat pengembangannya bagi kemajuan kesejahteraan masyarakat di daerah. Dan dapat dipahami, pemerintahan daerah memiliki kemampuan untuk mengenal karakteristik dan mengetahui tuntutan kebutuhan masing masing daerah secara realistis, seperti halnya potensi sumber daya alam di Pulau Sumbawa. 
Pulau Sumbawa yang memiliki luas 14.386 $\mathrm{km} 2$, merupakan wilayah yang berada di Provinsi Nusa Tenggara Barat, dan sebagai wilayah yang membawahi lokasi Gunung Tambora dengan titik ketinggian $2.824 \mathrm{~m}$ berstatus gunung api aktif.

Berdasarkan pemetaan daerah potensial pengembangan (Geowisata) kepariwisataan di Provinsi Nusa Tenggara Barat, Pulau sumbawa yang memiliki potensi sumber daya alam yang besar untuk pengembangan pembangunan pariwisata dengan julukan SAMOTA, yaitu Pulau Satonda, Moyo dan Gunung Tambora yang mempunyai karakteristik dengan nilai jual yang dapat berkonstribusi kepada penguatan PAD melalui kegiatan obyek wisata alam/ darat dan laut. Selain itu Pulau Moyo memiliki wisata bahari yang memeiliki panorama keindahan bawah laut yang indah. Hasil studi dari berbagai sumber, potensi Geowisata di Pulau Moyo yang berpeluang dikembangakn diantaranya adalah ${ }^{2}$ : Tanjung Pasir, air terjun matajitu, gua air manis dan gua liang petang. Gunung Tambora adalah gunung yang sangat terkenal di dunia karena letusan dahsaytanya pada tanggal 10-11 April 1815 yang menyebabkan korban jiwa 92.000 jiwa $^{3}$. Dari letusan tersebut berdampak pada potensi yang besar sekali dianataranya: air, mineral batuan gunung api, tanah (lahan pertanian, lahan spana untuk rans peternakan sapi, kerbau dan kuda, panas bumi dan aspek umbevwisata. Potensi PAD yang lainnya adalah Pulau Satonda yang merupakan pulau gunung api yang letaknya di sebelah barat laut Gunung Tambora berjarak $26 \mathrm{~km} .{ }^{4}$ Pulau Satonda memeiliki keindahan alam dengan berbagai potensi yang ada terutama Sumbaer Daya Alam bawah laut.

Potensi alam tersebut dapat memberikan konstribusi yang sangat berpengaruh terhadap menguatnya sumber penerimaan daerah melalui PAD dan merupakan indikator yang mengambarkan realisasi dari kemampuan daerah otonom dalam melaksanakan urusan

${ }^{2}$ Heryadi Rachmat.(2011). Geowisata Nusa Tenggara Barat, IAGI Pengda NTB, hlm.63.

${ }^{3}$ Ibid., hlm.69-70.

${ }^{4}$ Ibid., hlm.101-102. rumah tangga sendiri sesuai prinsip otonomi daerah. Karena ciri atau syarat untuk dapat disebut sebagai suatu daerah otonom adalah, mempunyai hak dan kemampuan untuk menggali sumber penerimaan sendiri sebagai sumber pembiayaan urusan urusan otonomi daerah, berdasarkan kebijakan pemerintahan daerah. Karena prinsip otonomi daerah yang memberikan kewenangan yang besar/luas kepada pemerintahan daerah, agar mempunyai kekuatan untuk melakukan perbuatan hukum secara mandiri dalam bentuk produk hukum daerah termasuk perbuatan hukum dengan pihak lain. Oleh karena itu, pemerintahan daerah mempunyai hak keleluasaan untuk bertindak/berbuat dalam urusan rumah tangga daerah, dan memiliki kewajiban yang mengikat untuk dilaksanakan dalam penyelenggara urusan pemerintahan dalam hubungannya dengan prinsip otonomi luas, nyata dan tanggung jawab.

Dengan demikian, pemerintahan daerah mempunyai hak untuk mengatur dan mengurus pengeloaan potensi sumber daya alam yang secara nyata dimiliki oleh daerah setempat. Dan hal yang sangat penting adalah merealisasikanaspekkewajibansertatanggung jawab dalam rangka memberdayakan potensi potensi sebagai sumber penerimaan tersebut yang berkonstribusi pada besar dan kuatnya PAD, sehingga menjadi daerah yang mampu mendanai urusan rumah tangga daerah secara dominan dari sumber penerimaan sendiri. Karena secara faktual, daerah daerak otonom kabupaten/kota di Provinsi Nusa Tenggara Barat mempunyai keadaan sumber pembiayaan penyelenggaraan urusan pemerintahan dengan ketergantungan kepada sumber dana dari pemerintah pusat sangat dominan. Karena itu, inovasi merumuskan regulasi dan kreatifitas menjalankan kebijakan sebagai suatu kewajiban bagi elemen penyelenggara pemerintahan daerah dalam mengoptimalisasi potensi sumber penerimaan bagi PAD sebagai unsur yang esensial dalam otonomi daerah. Dan potensi potensi yang nyata sebagaimana tersebut di atas menjadi tanggung jawab yang 
melekat pada daerah otonom untuk dapat berdayaguna bagi peningkatan kesejahteraan masyarakat setempat. Melalui kemampuan merumuskan regulasi merupakan dasar keabsahan bertindak, dan kecerdasan menjalankan kebijakan sebagai alasan pembenar secara hukum atas kewenangan untuk mengoptimalkan PAD. Berdasarkan latar belakang di atas, maka rumusan maslah yang dapat diangkat dianataranya adalah : peluang dan tantangan dalam pengelolaan sumberdaya alam dalam rangka optimalisasi PAD studi di SAMOTA.

\section{B. METODE PENELITIAN}

\section{a. Pendekatan Yang Digunakan}

Di dalam penelitian hukum terdapat beberapa pendekatan sesuai dengan karakter dan jenis penelitian. ${ }^{5}$ Dengan pendekatan tersebut, peneliti akan mendapatkan informasi dari berbagai aspek mengenai issu yang sedang dicoba untuk dicarai jawabannya. Guna menjawab permasalahan dalam penelitian ini, adapun pendekatan-pendekatan yang digunakan diantaranya adalah: ${ }^{6}$

(1)Pendekatanperaturanperundang-undangan (statute approach) yakni pendekatan yang dilakukan dengan menelaah beberapa PeraturanPerundangundangantertentudan/ atau regulasi yang bersangkut paut dengan issu hukum yang menjadi obyek diteliti dan sejalandenganfenomenaempirisberkenaan dengan penerapan hukum positif.

(2)Pendekatan konseptual (conceptual approach) yaitu pendekatan yang mengkaji dari aspek kepustakaan ilmu hukum berkaitan dengan teori, asas, doktrin maupun konsep dari pandangan para ahli yang berkembang mempengaruhi referensi hukum, terutama yang berkenaan dengan

5 Peter Mahmud Marzuki.(2005). Penelitian Hukum, Jakarta: Kencana, hlm.93. Dalam bukunya di kemukakan, pendekatan-pendekatan yang digunakan dalam penelitian hukum adalah pendekatan Undang-undang (statute approach), pendekatan kasus (case approach), pendekatan historis (historical approach), pendekatan komparatif (komparative approach), dan pendekatan konseptual (conceptual approach).

${ }^{6}$ Ibid., hlm.95. permasalahanyangdibahasdalampenelitian ini.

(3)Pendekatan sosiologis (sociological approach), yaitu pendekatan untuk mengamati dan menghimpun bahan dan informasi berkenaan dengan sikap tindak/ perilaku dari subyek yang mempunyai hubungan hukum dengan obyek yang diatur dalam penerapan hukum yang berlaku.

\section{b. Spesifikasi Penelitian}

Tipe kajian dalam penelitian ini adalah bersifat normatif empiris yang bertujuan untuk mengkaji mengenai isi hukum positif yang ditegakkan sebagaimana seharusnya (dassaien) dan untuk dianalisis/evaluasi dalam penerapan sebagaimana senyatanya (dassolen) atau dengan kata lain untuk mengetahui dan memahami daya/cara kerja hukum positif dalam keadaan yang seharusnya dengan hasil kerja hukum itu sesuai dengan peristiwa senyatanya dalam penerapan.

\section{c. Jenis Dan Sumber Bahan Hukum}

Jenis dan sumber bahan hukum yang digunakan dalam penelitian ini diantaranya;

1. Bahan hukum primer yakni bahan hukum yang terhimpun dalam hukum positif berbentuk Peraturan Perundang undangan danbahan/datalapangan yangberhubungan dengan peristiwa dan perbuatan dari subyek atas obyek yang mengikat secara hukum sesuai dengan ruang lingkip penelitian ini;

2. Bahan hukum sekunder adalah bahan hukum yang diperoleh dari buku, jurnaljurnal hukum, pendapat para sarjana, serta symposium yang dilakukan pakar terkait dengan permasalahan yang diangkat dalam penelitian ini;

3. Bahan hukum tersier adalah bahan hukum yang memberikan petunjuk atau penjelasan bermaknaterhadapbahanhukumprimerdan sekunder seperti kamus, ensiklopedia dan lain-lain.

\section{d. Teknik Pengumpulan Data/ Bahan Hu- kum}

Data dikumpulkan dengan cara melakukan penelitian lapangan dalam melalui 
pengamatan dan wawancara kepada informan maupun responden, sedangkan bahan hukum dapat dilakukan dengan menghimpun bahan bahan hukum berupa peraturan perundang undangan sebagai hukum positif dan referensi hukum berupa buku-buku literatur, maupun karya karya ilmiah lainnya yang berkaitan dengan obyek yang ditili .

\section{PEMBAHASAN}

\section{Peluang dan tantangan dalam pengelolaan sumberdaya alam dalam rangka optimal- isasi PAD studi di SAMOTA}

\section{Peluang pengelolaan PAD di SAMOTA}

\subsection{Moyo}

Pulau Moyo merupakan sebuah pulau unik yang dikenal dengan keindahan alam dan taman bawah lautnya yang menawan, pulau ini berada di sebelah utara pulau Sumbawa dengan luas $350 \mathrm{~km} 2$, dengan garis pantai $88 \mathrm{~km}$ dan ketinggian maksimum 671 meter. Keindahan yang istimewa membuat pulau moyo ini banyak didatangi para wisatawan dan tidak sedikit para tokoh terkenal yang berkunjung ke pulau ini seperti Pangeran William, Mick Jagger dan pesepakbola mantan kiper Manchester United Edwin Van Der Sar dan para artis local yang sinngah untuk menyaksikan indahnya pulau moyo, tidak hanya itu pulau moyo ini juga di gemari para pasangan yang baru menikah sebagai tempat bulan madu yang romantis dan beberapa destinasi di pulau moyo ini memang sangat memanjakan.

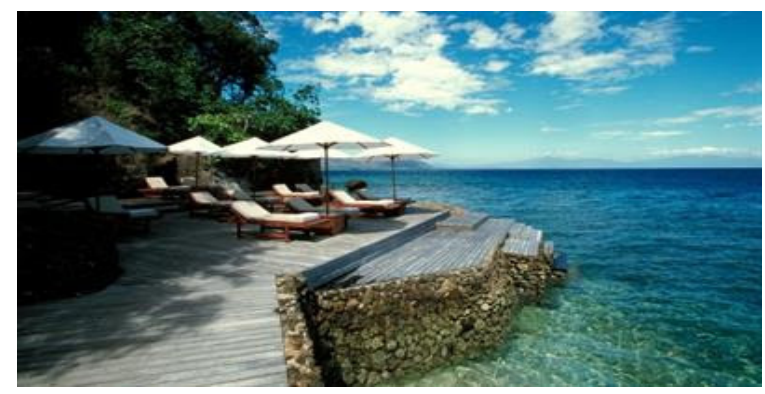

Wisata pulau moyo

Bagi anda yang berencana mengisi liburan ke pulau moyo berikut matajatim.com akan membagikan beberapa destinasi menarik yang bisa anda kunjungi saat berlibur ke pulau moyo tersebut. inilah 5 destinasi populer di pulau moyo yang banyak di gemari para wisatawan.

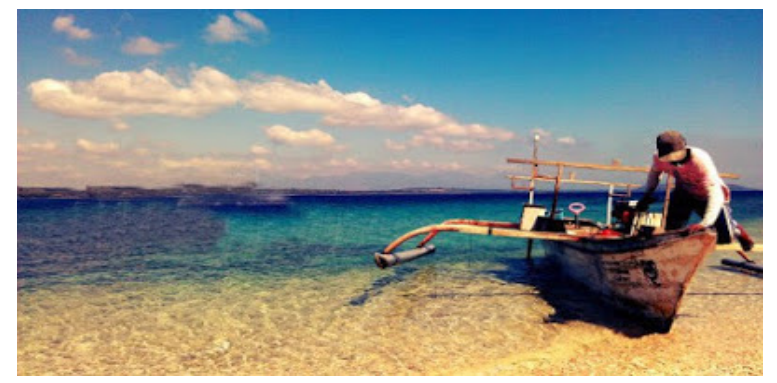

Pantai tanjung pasir (via visitnusatenggara.

$$
\text { blogspot.co.id) }
$$

Bagi anda yang suka dengan pemandangan laut maka jangan lewatkan pantai yang satu ini saat berkunjung ke pulau moyo, pantai tanjung pasir yang berlokasi di ujung selatan pulau ini memiliki keindahan yang indah tidak hanya pasir putihnya yang menawan keindahan bawah lautnya juga sangat memanjakan aneka terumbu karang yang cantik yang berhiaskan aneka jenis ikan akan anda jumpai saat mengexplore bawah laut pantai tanjung pasir ini, diarea pantai ini juga terdapat tempat-tempat untuk bersantai dengan view yang romantis.

\section{Pantai Air Manis}

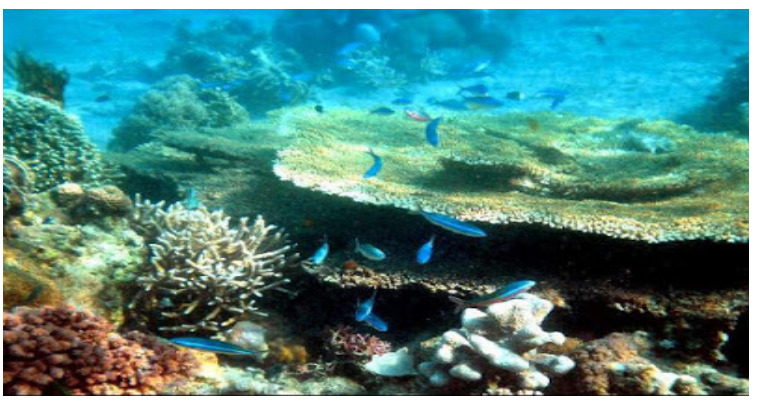

Keindahan bawah laut pantai air manis (via lombok.panduanwisata.id)

Pantai air manis ini juga tidak kalah menariknya, berpetualang di pantai ini akan memberikan kesan yang special apalagi bersama pasangan, anda bisa melakukan camping, snorkeling dan diving di pantai ini, keindahan bawah lautnya seperti warna-warni terumbu karang dan biota bawah lautnya akan membuat anda lupa daratan, dan uniknya di kawasan ini terdapat sebuah hutan tropis yang dihuni oleh beragam jenis hewan seperti 
burung kakatua, rusa, babi hutan dan lainnya yang akan membuat petualangan anda lebih seru.

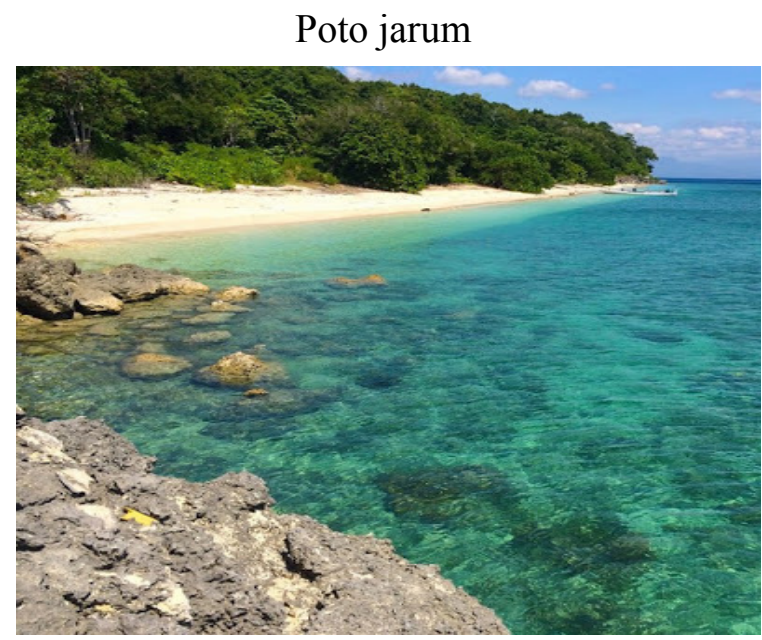

viaforum.detik.com

Satu lagi destinasi pantai yang patut untuk dikunjungi saat berlibur ke pulau moyo yaitu poto jarum, kawasan ini juga memiliki pemandangan pantai yang cukup indah dan tak sedikit yang menjadikan pantai ini sebagai tempat untuk berjemur sembari menikmati view laut yang menggoda.

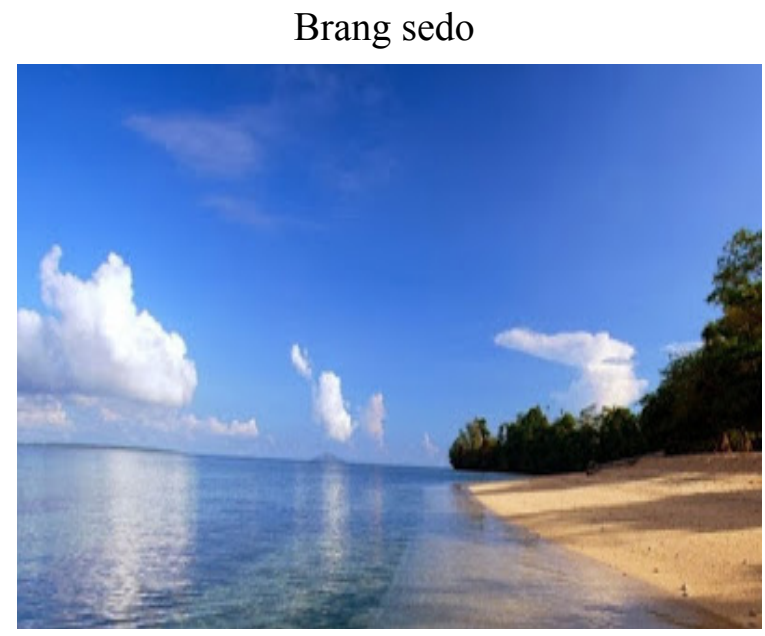

( http://maukemanacom.blogspot.co.id/)

Di kawasan ini juga terdapat sebuah pantai yang indah dengan view yang masih alami, di area brang sedo ini pengunjung bisa melakukan aktivitas berkemah dan aktivitas lainnya seperti diving dan senorkeling.

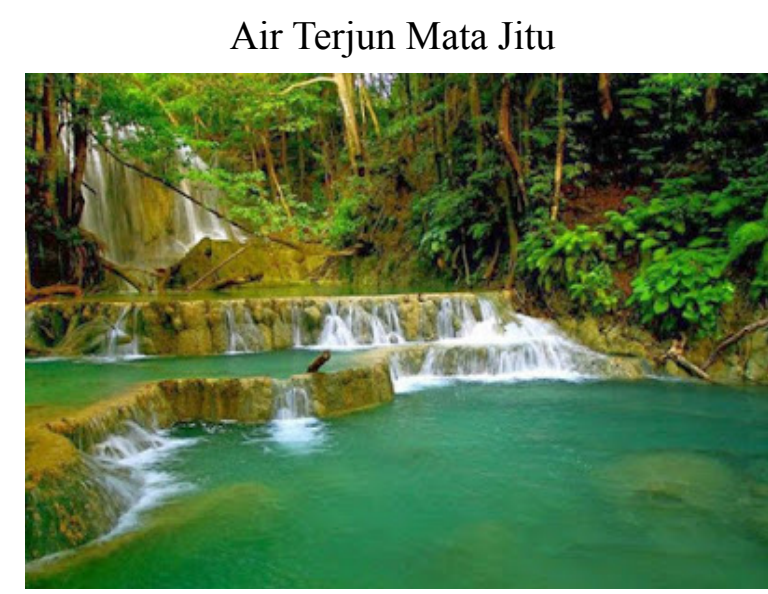

air terjun mata jitu (via www.indonesiatourism.com)

Selain destinasi pantai pulau moyo ini juga memiliki wisata air terjun dengan keindahan alamnya yang alami dan menyejukkan, aliran air yang cukup tenang jernih dengan warna hijau kebiruan akan membuat mata siapa saja tak sabar ingin segera menceburkan diri di kolam tersebut, selain itu di lokasi ini juga terdapat 7 kolam yang tidak boleh digunakan untuk berenang, namun jangan kawatir pengelola sudah menyiapkan spot kusus untuk anda yang ingin merasakan sensasi berenang di air terjun mata jitu ini.

\subsection{Tambaora}

Gunung Tambora (Tomboro) adalah sebuah stratovolcano aktif yang terletak di pulau Sumbawa, Indonesia. ${ }^{7}$ Gunung ini terletak di dua kabupaten, yaitu Kabupaten Dompu (sebagian kaki sisi selatan sampai barat laut, dan Kabupaten Bima (bagian lereng sisi selatan hingga barat laut, dan kaki hingga puncak sisi timur hingga utara), Provinsi Nusa Tenggara Barat, tepatnya pada $8^{\circ} 15^{\prime}$ LS dan $118^{\circ}$ BT. Gunung ini terletak baik di sisi utara dan selatan kerak oseanik. Tambora terbentuk oleh zona subduksi di bawahnya. Hal ini meningkatkan ketinggian Tambora sampai $4.300 \mathrm{~m}^{8}$ yang membuat gunung ini pernah menjadi salah satu puncak

\footnotetext{
7"Tambora". Global Volcanism Program. Smithsonian Institution. Diakses tanggal 17 Oktober.

8 Stothers, Richard B. (1984). "The Great Tambora Eruption in 1815 and Its Aftermath". Science 224 (4654): 1191-1198
} 
tertinggi di Nusantara dan mengeringkan dapur magma besar di dalam gunung ini. Perlu waktu seabad untuk mengisi kembali dapur magma tersebut.

Aktivitas vulkanik gunung berapi ini mencapai puncaknya pada bulan April tahun 1815 ketika meletus dalam skala tujuh pada Volcanic Explosivity Index. ${ }^{9}$

Letusan tersebut menjadi letusan tebesar sejak letusan danau Taupo pada tahun $181 .{ }^{10}$ Letusan gunung ini terdengar hingga pulau Sumatra (lebih dari $2.000 \mathrm{~km}$ ). Abu vulkanik jatuh di Kalimantan, Sulawesi, Jawa dan Maluku. Letusan gunung ini menyebabkan kematian hingga tidak kurang dari 71.000 orang dengan $11.000-12.000$ di antaranya terbunuh secara langsung akibat dari letusan tersebut.

Bahkan beberapa peneliti memperkirakan sampai 92.000 orang terbunuh, tetapi angka ini diragukan karena berdasarkan atas perkiraan yang terlalu tinggi. ${ }^{11}$ Lebih dari itu, letusan gunung ini menyebabkan perubahan iklim dunia. Satu tahun berikutnya (1816) sering disebut sebagai Tahun tanpa musim panas karena perubahan drastis dari cuaca Amerika Utara dan Eropa karena debu yang dihasilkan dari letusan Tambora ini. Akibat perubahan iklim yang drastis ini banyak panen yang gagal dan kematian ternak di Belahan Utara yang menyebabkan terjadinya kelaparan terburuk pada abad ke19.[4].

Selama penggalian arkeologi tahun 2004, tim arkeolog menemukan sisa kebudayaan yang terkubur oleh letusan tahun $1815 \mathrm{di}$ kedalaman 3 meter pada endapan piroklastik. ${ }^{12}$ Artifak-artifak tersebut ditemukan pada

9 Degens, E.T.; Buch, B (1989). "Sedimentological events in Saleh Bay, off Mount Tambora". Netherlands Journal of Sea Research 24 (4): 399-404.

${ }^{10}$ Oppenheimer, Clive .(2003). "Climatic, environmental and human consequences of the largest known historic eruption: Tambora volcano (Indonesia) 1815". Progress in Physical Geography 27 (2): 230-259.

${ }^{11}$ Tanguy, J.-C.; Scarth, A., Ribière, C., Tjetjep, W. S. (1998). "Victims from volcanic eruptions: a revised database". Bulletin of Volcanology 60 (2): $137-144$

${ }^{12}$ University of Rhode Island (2006-02-27). URI volcanologist discovers lost kingdom of Tambora. Siaran pers. Diakses pada 6 Oktober. posisi yang sama ketika terjadi letusan pada tahun 1815. Karena ciri-ciri yang serupa inilah, temuan tersebut sering disebut sebagai Pompeii dari timur.

Akibat letusan tahun 1815, Gunung Tambora membentuk kaldera kering terbesar di Indonesia dan ketinggiannya berkurang dari sekitar 4.000 meter menjadi 2.850 meter hingga sekarang.

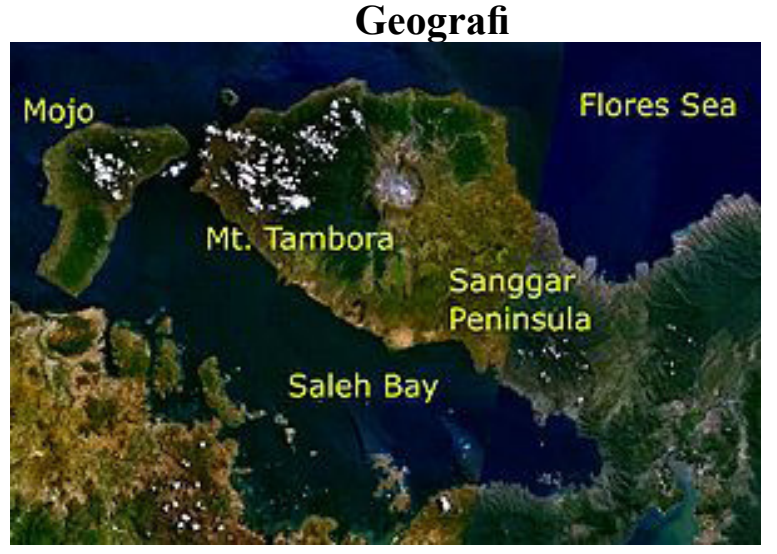

Pemandangan gunung Tambora dan sekelilingnya dari udara.

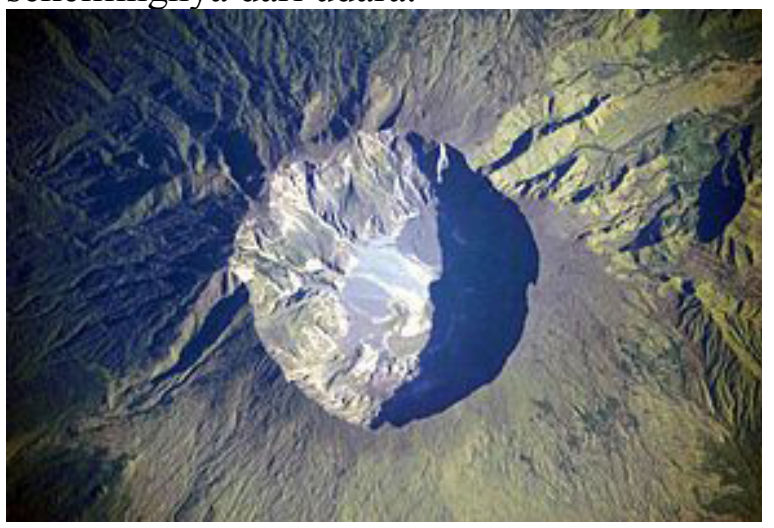

Kawah di puncak gunung Tambora.

Gunung Tambora terletak di pulau Sumbawa yang merupakan bagian dari kepulauan Nusa Tenggara. Gunung ini adalah bagian dari busur Sunda, tali dari kepulauan vulkanik yang membentuk rantai selatan kepulauan Indonesia. ${ }^{13}$ Tambora membentuk semenanjungnya sendiri di pulau Sumbawa yang disebut semenanjung Sanggar. Di sisi utara semenanjung tersebut, terdapat laut Flores, dan di sebelah selatan terdapat teluk Saleh dengan panjang

${ }^{13}$ Foden, J. (1986). "The petrology of Tambora volcano, Indonesia: A model for the 1815 eruption". Journal of Volcanology and Geothermal Research 27 (1-2): 1-41. 
$86 \mathrm{~km}$ dan lebar $36 \mathrm{~km}$. Pada mulut teluk Saleh, terdapat pulau kecil yang disebut Mojo.

Selain seismologis dan vulkanologis yang mengamati aktivitas gunung tersebut, gunung Tambora adalah daerah untuk riset ilmiah arkeolog dan biologi. Gunung ini juga menarik turis untuk mendaki gunung dan aktivitas margasatwa. Dompu dan Bima adalah kota yang letaknya paling dekat dengan gunung ini. Di lereng gunung Tambora, terdapat beberapa desa. Di sebelah timur terdapat desa Sanggar. Di sebelah barat laut, terdapat desa Doro Peti dan desa Pesanggrahan. Di sebelah barat, terdapat desa Calabai.

Terdapat dua jalur pendakian untuk mencapai kaldera gunung Tambora. Rute pertama dimulai dari desa Doro Mboha yang terletak di sisi tenggara gunung Tambora. Rute ini mengikuti jalan beraspal melalui perkebunan kacang mede sampai akhirnya mencapai ketinggian $1.150 \mathrm{~m}$ di atas permukaan laut. Rute ini berakhir di bagian selatan kaldera dengan ketinggian $1.950 \mathrm{~m}$ yang dapat dicapai oleh titik pertengahan jalur pendakian. Lokasi ini biasanya digunakan sebagai kemah untuk mengamati aktivitas vulkanik karena hanya memerlukan waktu satu jam untuk mencapai kaldera. Rute kedua dimulai dari desa Pancasila di sisi barat laut gunung Tambora. Jika menggunakan rute kedua, maka kaldera hanya dapat dicapai dengan berjalan kaki.

\section{Bukti arkeologi}

Pada musim panas tahun 2004, tim dari Universitas Rhode Island, Universitas North Carolina di Wilmington, dan direktorat vulkanologi Indonesia, dipimpin oleh Haraldur Sigurdsson, memulai sebuah penggalian arkeologi di gunung Tambora. Setelah enam minggu, tim tersebut menggali bukti adanya kebudayaan yang hilang yang musnah karena letusan gunung Tambora. Situs tersebut terletak $25 \mathrm{~km}$ sebelah barat kaldera, di dalam hutam, $5 \mathrm{~km}$ dari pantai. Tim tersebut harus melewati endapan batu apung vulkanik dan abu dengan tebal $3 \mathrm{~m}$.
Tim tersebut menggunakan radar penembus tanah untuk mencari lokasi rumah kecil yang terkubur. Mereka menggali kembali rumah dan mereka menemukan sisa dua orang dewasa, dan juga mangkuk perunggu, peralatan besi dan artifak lainnya. Desain dan dekorasi artifak memiliki kesamaan dengan artifak dari Vietnam dan Kamboja. Uji coba dilakukan menggunakan teknik karbonisasi memperjelas bahwa mereka terbentuk dari pensil arang yang dibentuk oleh panas magma. Semua orang, rumah dan kebudayaan dibiarkan seperti saat mereka berada tahun 1815 .

Sigurdsson menyebut kebudayaan ini sebagai Pompeii dari timur. Berdasarkan artifak yang ditemukan, yang mayoritas benda perunggu, tim menyatakan bahwa orang-orang tersebut tidak miskin. Bukti sejarah menunjukan bahwa orang di pulau Sumbawa terkenal di Hindia Timur untuk madu, kuda, kayu sepang (caesalpinia sappan), memproduksi dye merah, dan cendana yang digunakan untuk dupa dan pengobatan. Daerah ini diketahui produktif dalam bidang pertanian.

Penemua arkeologi memperjelas bahwa terdapat kebudayaan yang hancur karena letusan tahun 1815. Sebutan Kerajaan Tambora yang hilang disebut oleh media. Dengan penemuan ini, Sigurdsson bermaksud untuk kembali ke Tambora tahun 2007 untuk mencari sisa desa, dan berharap dapat menemukan istana.

\section{Ekosistem}

Tim penelitian yang dipimpin oleh ahli botani Swiss, Heinrich Zollinger, tiba di pulau Sumbawa tahun $1847 .{ }^{14}$ Misi Zollinger adalah untuk mempelajari letusan dan pengaruhnya terhadap ekosistem lokal. Ia adalah orang pertama yang memanjat ke puncak gunung Tambora setelah letusan gunung tersebut. Gunung tersebut masih tertutup oleh asap. Ketika Zollinger memanjat, kakinya tenggelam beberapa kali melalui kerak permukaan tipis menuju

14 "Heinrich Zollinger". Zollinger Family History Research. Diakses tanggal 14 November. 
lapisan hangat yang seperti sulfur. Beberapa tumbuh-tumbuhan kembali tumbuh dan beberapa pohon diamati di lereng yang lebih rendah. Hutan Casuarina dicatat pada 2.200$2.550 \mathrm{~m}$. Beberapa Imperata cylindrica juga dapat ditemukan.Penduduk mulai tinggal di gunung Tambora pada tahun 1907.

Penanaman kopi dimulai

pada tahun 1930-an di lereng bagian barat laut gunung Tambora, di desa Pekat. ${ }^{15}$ Hutan hujan yang disebut Duabangga moluccana telah tumbuh dengan ketinggian $1.0002 .800 \mathrm{~m} .^{16}$ ] Penanaman tersebut mencakupi daerah seluas 80.000 hektare $\left(800 \mathrm{~km}^{2}\right)$. Hutan hujan ditemukan oleh tim Belanda, dipimpin oleh Koster dan De Voogd tahun 1933.[30] Mereka memulai perjalanan di "daerah hampir tandus, kering dan panas" dan mereka memasuki "hutam hebat" dengan "raksasa hutan yang besar dan megah". Pada ketinggian $1.100 \mathrm{~m}$, mereka memasuki hutan montane. Pada ketinggian $1.800 \mathrm{~m}$, mereka menemukan Dodonaea viscosa yang didominasi oleh pohon Casuarina.

Di puncak, mereka menemukan sedikit Anaphalis viscida dan Wahlenbergia. 56 spesies burung ditemukan tahun 1896, termasuk Crested White-eye. 12 spesies lainnya ditemukan pada tahun 1981. Beberapa penelitian ahli ilmu hewan menemukan spesies burung lainnya di gunung, menghasilkan ditemukannya lebih dari 90 spesies burung. Kakatua-kecil Jambul-kuning, Murai Asia, Tiong Emas, Ayam hutan Hijau dan Perkici Pelangi diburu untuk dijual dan dipelihara oleh penduduk setempat. Gosong berkaki-jingga diburu untuk dimakan. Eksploitasi burung menyebabkan berkurangnya populasi burung. Yellowcrested Cockatoo hampir punah di pulau Sumbawa.

${ }^{15}$ de Jong Boers, B. (1995). "Mount Tambora in 1815: A Volcanic Eruption in Indonesia and its Aftermath". Indonesia 60: 37-59.

16 Trainor, C.R. (2002). "Birds of Gunung Tambora Sumbawa, Indonesia: effects of altitude, the 1815 catalysmic volcanic eruption and trade" (PDF). Forktail 18: 49-61.
Sejak tahun 1972, perusahaan penebangan komersial telah beroperasi di daerah ini, yang menyebabkan ancaman terhadap hutan hujan. Perusahaan penebangan memegang izin untuk menebang kayu di daerah seluas 20.000 hektare $\left(200 \mathrm{~km}^{2}\right)$, atau $25 \%$ dari jumlah luas daerah. Bagian hutan hujan lainnya digunakan untuk berburu. Di antara tanah berburu dan tanah penebangan, terdapat cagar alam, temat rusa, kerbau, babi hutan, kelelawar, rubah terbang, dan berbagai spesies reptil dan burung dapat ditemukan.

\subsection{Satonda}

Pulau satonda sebagai bagian dari kawasan wisata hunung tambora dan sekitarnya, adalah merupakan pulau gunungapi yang memiliki 2 (dua) buah danau kawah yang disisir air asin. Kedua danau tersebut memiliki ukuran dan kedalaman yag berbeda serta membentuk angka delapan. Sekitar danau kawah satonda di bagian luar maupun bagian dalamnya memiliki obyek wisata alam yang cukup menarik berupa taman laut, panorama alam perbukitan, flora dan fauna. Di samping itu pulau satonda juga memiliki sejarah geologi yang sagat unik dikaitkan dengan sejarah gunungapi tambora, sehingga sangat berpotensi untuk dikembangkan ssebagai salah satu tujuan obyek geowisata kelas dunia.

Secara geografis pulau satonda terletak pada koordinat 807' lintang selatan dan 117045' bujur timur.pulau satonda tidak hanya menjadi incaran dua kabupaten bertetangga akan tetapi diincar oleh para pakar dari macanegara, ini dapat dilihat dari kunjungan-kunjungan yang dilakukan dalam rangka kegiatan penelitian untuk menguak misteri-misteri yang tersembunyi di dalam perut pulau yang mungil itu. Kawasan wisata daerah ini muda dijangkau dari labuhan kanangan menggunakan speedboat sekitar 15 menit.

Obyek geowisata dan wisata lainnya yang berpotensi di dalam kawasan pulau satonda antara lain yang terkait dengan pembentukan danau kawah, morfologi pulau satonda 
dan danau kawah, koral, danau air asin, tinggi permukaan danau kawah dan air laut, didinding kawah yang berlapis, sumbat lava, mata air asin-payau, dan lain-lain.

Obyek geowisata lain di luar kawasan pulau satonda antara lain obyek geologi wisata pantai, gunungapi tambora, situs kerajaan yang tertimbun letusan gunung tambora 1815, gua, air terjun dan lain-lain.

Selain itu, pulau satonda adalah tempat yang tepat untuk menyalurkan hobi seperti panjat tebing dan lain-lain, karena disana terdapat tebing-tebing terjal, bukit-bukit berhutan dan semak belukar yang ditumbuhi bermacam-macam tumbuhan. Pulau satonda mengundang banyak ilmuan untuk melakukan penelitian mencari dan menemukan misteri apa yang terkadung di dalamnya dan lain sebagainya.

Selain potensi-potensi sebagai mana yang di uraukan di atas, sumber-sumber PAD lainya juga berupa tambang pasir biji besi, perkebunan, perikanan, peternakan, tambang galian C lainnya dan masih banyak lagi potensi yang lainnya.

Potensi lain yang dapat dijadikan unggulan dalam peningkatan PAD diantaranya alah menjadikan kawasan tertu dalam skala KEK (Kawasan Ekonomi Khusus) dan KAPET (Kawasan Pengembangan Ekonomi Terpadu).

Kawasan Ekonomi Khusus (KEK) adalah kawasan dengan batas tertentu yang tercangkup dalam daerah atau wilayah untuk menyelenggarakan fungsi perekonomian dan memperoleh fasilitas tertentu. KEK dikembangkan melalui penyiapan kawasan yang memiliki keunggulan geoekonomi dan geostrategi dan berfungsi untuk menampung kegiatan industri, ekspor, impor, dan kegiatan ekonomi lain yang memiliki nilai ekonomi tinggi dan daya saing internasional.

Pada dasarnya KEK dibentuk untuk membuat lingkungan kondusif bagi akitivitas investasi, ekspor, dan perdagangan guna mendorong laju pertumbuhan ekonomi serta sebagai katalis reformasi ekonomi. Untuk ide ini diinspirasi dari keberhasilan beberapa negara yang lebih dulu mengadopsinya, seperti Tiongkok dan India. Bahkan data-data empiris melukiskan bahwa KEK di negara tersebut mampu menarik para investor, terutama investor asing untuk berinvestasi dan menciptakan lapangan kerja. Hal itu tak lain karena kemudahan yang didapat para investor, kemudahan itu berbentuk kemudahan di bidang fiskal, perpajakan dan kepabeanan. Bahkan ada juga di bidang non-fiskal, seperti kemudahan birokrasi, pengaturan khusus di bidang ketenagakerjaan dan keimigrasian, serta pelayanan yang efisien dan ketertiban di dalam kawasan.

Zona bebas dan entrepots telah digunakan selama berabad-abad untuk menjamin penyimpanan gratis dan pertukaran sepanjang rute perdagangan. KEK Modern muncul dari tahun 1950-an di negara-negara industri. Yang pertama adalah di Bandara Shannon di Clare, Irlandia. Dari tahun 1970 dan seterusnya, zona menyediakan manufaktur padat karya telah dibentuk, dimulai di Amerika Latin dan Asia Timur. Zona ini menarik investasi dari perusahaan-perusahaan multinasional.

Sejak pemerintah mengeluarkan Peraturan Pemerintah (PP) No.2 Tahun 2011 tentang Penyelenggaraan Kawasan Ekonomi Khusus (KEK), terlihat pemerintah semakin nyata dalam mempercepat dan melakukan pemerataan pembangunan ekonomi di Indonesia. Percepatan dan pembangunan ekonomi akan mempengaruhi langsung maupun tidak langsung terhadap perkembangan pembangunan suatu wilayah. Sebelum peraturan terkait KEK dikeluarkan, pemerintah sudah sejak lama berusaha melakukan tindakan serius dalam mempercepat dan melakukan pemerataan pembangunan di seluruh kawasan Indonesia.

Salah satu program pemerintah dahulu hingga saat ini yang terus berjalan dalam melakukan pemerataan pembangunan di Indonesia, yakni Kawasan Pengembangan Ekonomi Terpadu (KAPET). Untuk itu tulisan ini berupaya mengupas secara singkat tentang KAPET dan KEK serta perbedaan diantara 
program percepatan pembangunan ekonomi wilayah tersebut satu sama lain.

KAPET adalah wilayah geografis dengan batas-batas tertentu yang memiliki potensi untuk cepat tumbuh, mempunyai sektor unggulan yang dapat mengerakkan pertumbuhan ekonomi wilayah dan memerlukan dana investasi yang besar bagi pengembangannya serta penetapan lokasi dan Badan Pengelolanya dilakukan melalui Keputusan Presiden (Bappenas, 2013). KAPET merupakan sebuah pendekatan dalam rangka menterpadukan potensi kawasan untuk mempercepat pembangunan dan pergerakan ekonomi melalui pengembangan sektor unggulan yang menjadi penggerak utama (prime mover) kawasan yang bertumpu pada prakarsa daerah dan masyarakat, memiliki sumberdaya, posisi ke akses pasar, sektor unggulan dan memberikan dampak pertumbuhan pada wilayah sekitarnya. Kawasan Pengembangan Ekonomi Terpadu (KAPET) dibentuk berdasarkan Keputusan Presiden (Keppres) No. 9 Tahun 1998 yang merupakan perubahan atas Keputusan Presiden (Keppres) No.89 Tahun 1996 tentang Kawasan Pengembangan Ekonomi Terpadu.

Berdasarkan Keputusan Presiden tersebut, kemudian dikeluarkan Keputusan Presiden lainnya tentang penetapan lokasi KAPET, yaitu 14 KAPET, yang terdiri dari 12 KAPET di Kawasan Timur Indonesia (KTI) dan dua KAPET di Kawasan Barat Indonesia (KBI). Seiring dengan perkembangan otonomi daerah, kebijakan KAPET disempurnakan kembali melalui Keputusan Presiden (Keppres) No. 150 Tahun 2000. Keempat belas KAPET tersebut, yakni KAPET Biak, Batulicin, Sasamba, Sanggau (Khatulistiwa), Manado-Bitung, Mbay, Parepare, Seram, Bima, Palapas (Batui), Bukari, DAS Kakab, Natuna dan Sabang.

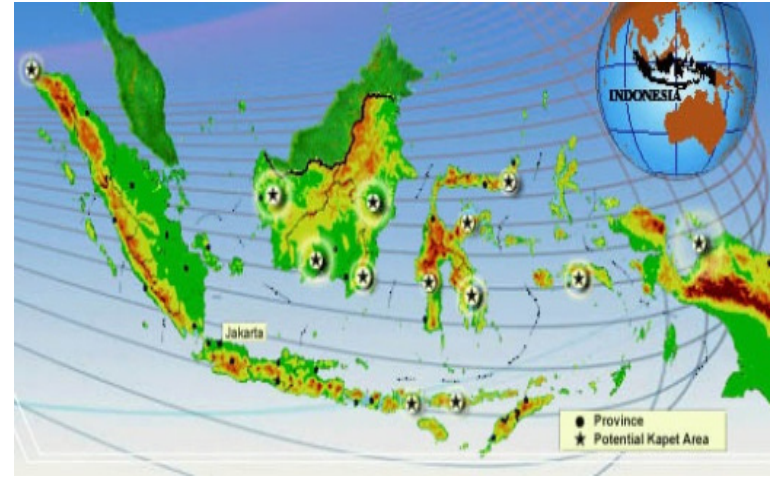

(Persebaran 13 Lokasi KAPET. Sumber: www. kapet.net)

Dengan adanya program percepatan dan pemerataan pembangunan ekonomi-wilayah yang dijalankan oleh pemerintah pusat-daerah tersebut, diharapakan KAPET dan KEK dapat menjadi "trigger" di wilayah sekitarnya sehingga dapat meningkatkan kesejahteraan masyarakat lokal dan dapat menjadi elemen pendukung pelaksanaan Masterplan Percepatan dan Perluasan Pembangunan Ekonomi Indonesia (MP3EI). Dengan kata lain, diharapkan pengembangan KAPET dan KEK dapat menterpadukan potensi kawasan untuk mempercepat pembangunan dan pergerakan ekonomi melalui pengembangan sektor unggulan yang menjadi penggerak utama kawasan bertumpu pada prakarsa daerah dan masyarakat, memiliki sumberdaya, posisi ke akses pasar, sektor unggulan dan memberikan dampak pertumbuhan pada wilayah sekitarnya. Dengan pengembangan KAPET dan KEK diarahkan dapat mendorong (sub)sektor unggulan masingmasing Koridor Ekonomi MP3EI. Dan juga pengembangan KAPET dan KEK dilakukan dengan peningkatan daya saing pada sektor hulu-hilir untuk memberikan nilai tambah dan pencitraan inovasi kepada komoditas yang dihasilkan untuk menciptakan spesialisasi hasil produksi.

KAPET dan KEK seyogyanya dapat saling mendukung dan melengkapi satu sama lain dalam mengembangkan dan melakukan pemerataan pembangunan ekonomi-wilayah di Indonesia sehingga dapat mewujudkan impian dan cita-cita "founding fathers"di dalam sila ke-5 Pancasila, yakni "keadilan 
sosial bagi seluruh rakyat Indonesi"a dan pembukaan UUD 1945, yaitu “..memajukan kesejahteraan umum..”.

Peneliti menilai kawasan satonda, Moyo dan Tambora atau disebut Samota di Pulau Sumbawa, Nusa Tenggara Barat, berpeluang menjadi kawasan ekonomi maju karena potensi sumber daya alamnya. Kawasan Samota menjadi titik konsen Pemerintah Provinsi NTB untuk dikembangkan ke depan.

Kawasan Samota berada di tiga kabupaten, yakni Kabupaten Sumbawa, Dompu dan Bima. Daerah ini cocok untuk pengembangan minapolitan, pariwisata dan pertanian.

Satonda cocok dikembangkan sebagai kawasan agribisnis, minapolitan, budi daya rumput laut, udang dan kerapu, dan tambak serta wisata bahari.

Potensi areal dan produksi perikanan tangkap mencapai 2.400 ton/tahun, potensi tambak 8.600 hektare (ha), budi daya rumput laut 9.000 ha, ikan bersirip 980 ha dan mutiara 740 ha. Nilai produksi total per tahun mencapai Rp11,608 triliun, terdiri atas rumput laut $\mathrm{Rp} 2,6$ triliun, udang $\mathrm{Rp5}, 16$ triliun, ikan kerapu dan lainnya $\mathrm{Rp} 2,8$ triliun dan perikanan tangkap Rp48 miliar.

Potensi serapan tenaga kerja dari pengembangan sektor pariwisata dan pendukungnya di kawasan Samota bisa mencapai 14.935 orang dan ketahanan pangan 70.584 orang. Perhitungan nilai ekonomi dari potensi sumber daya alam Samota dilakukan oleh mantan Menteri Kelautan dan Perikanan Rokhmin Dahuri.

Sebagai bentuk keseriusan Pemerintah Provinsi NTB ditandai dengan terbentuknya Tim Percepatan Pembangunan Samota dan dilakukannya penelitian-penelitian tentang untuk mengkaji kelembagaan yang tepat bagi samota. Tim percepatan dan pengkajian ini melibatkan pakar nasional dan pakar lokal seperti Prof Rokhmin Dahuri, dan Dr Son Diamar dan peneliti-peneliti handal dari Universitas Mataram.

Peneliti berharap Samota menjadi salah satu instrumen yang dimiliki NTB untuk mengentaskan kemiskinan. Tentu konsep pembangunannya harus mengikutsertakan masyarakat, juga Samota bisa diarahkan menjadi kawasan ekonomi populer seperti di daerah lain. Misalnya, kawasan Makassar, Maros, Sunguminasa, dan Takalar atau disebut Maminasata. Ada juga Satuan Wilayah Pembangunan (SWP) yang disebut Gerbangkertosusila atau gabungan kawasan ekonomi Kabupaten Gresik, Bangkalan, Mojokerto, Surabaya, Sidoarjo, dan Lamongan di Provinsi Jawa Timur.

\section{Kendala dalam pengelolaan sumberda- ya alam dalam optimalisasi pendapatan PAD di SAMOTA}

Berdasarkan penjelasan tersebut diatas, ada beberapa kendala dalam pengelolaan Sumberdaya alam tersebut, dianataranya ada yang bersifat teknis dan ada pula yang bersifat non teknis. Adapun kendala yang bersifat teknis dianataranya cadalah:

1. Masih minimnya sumberdaya manusia,

2. Penguasaan teknoli yang masih lemah,

3. Rugalasiyangbelummemadai,kendalayang bersifat non teknis dinataranya :

1. Inprastruktur yang belum menunjang,

2. Selain itu kendala lain juga diantarannya adalah persoalan kepentingan politik dalam mewujudkan kemajuan daerah secara bersama.

4. Lemahnya koordinasi atara pemerintah daerah provinsi dengan pemerintah daerah kabupaten/kota,

5. Kurangnya sosialisai pada masyarakat dll.

\section{KESIMPULAN}

Dari penjelasan tersebut diatas, dapat ditarik kesimpulan sebagai berikut: bahwa dalam optimalisasi sumberdaya alam dalam rangka peningkatan PAD sepatutnya dikelola dengan baik. hal ini penting untuk meningkatan PAD daerah sehingga otonomi daerah bisa berjalan tanpa harus menunggu dana dari pemerintah pusat, selain itu dengan pengelolaan sumbver-sumber PAD tersebut, kinerja daerah dapat maksimal untuk memberikan pelayanan kepada masyarakat dan menjadikan lebih baik dan maju 


\section{DAFTAR PUSTAKA}

Degens,

E.T.;

B.(1989). "Sedimentological events in Saleh Bay, off Mount Tambora". Netherlands Journal of Sea Research.

de Jong Boers, B.(1995). "Mount Tambora in 1815: A Volcanic Eruption in Indonesia and its Aftermath".

Foden, J.(1986). "The petrology of Tambora volcano, Indonesia: A model for the 1815 eruption". Journal of Volcanology and Geothermal Research. Heinrich Zollinger. Zollinger Family History Research. Diakses tanggal 14 November.

Heryadi Rachmat.(2011). Geowisata Nusa Tenggara Barat, IAGI Pengda NTB.

Peter Mahmud Marzuki.(2005). Penelitian Hukum, Jakarta: Kencana.

"Tambora". Global Volcanism Program. Smithsonian Institution. Diakses tanggal 17 Oktober.

Oppenheimer, Clive. "Climatic, environmental and human consequences of the largest known historic eruption: Tambora volcano (Indonesia) 1815". Progress in Physical Geography. 2003.

Syamsudin Haris, Desentralisasi \& otonomi Daerah, LIPI Press, Jakarta, 2005

Stothers, Richard B. "The Great Tambora Eruption in 1815 and Its Aftermath". 1984

Tanguy, J.-C.; Scarth, A., Ribière, C., Tjetjep, W. S. "Victims from volcanic eruptions: a revised database”. Bulletin of Volcanology. 1998.

Trainor, C.R. "Birds of Gunung Tambora, Sumbawa, Indonesia: effects of altitude, the 1815 catalysmic volcanic eruption and trade" (PDF).
2002.

University of Rhode Island (2006-02-27). URI volcanologist discovers lost kingdom of Tambora. Siaran pers. Diakses pada 6 Oktober. 